\title{
sciendo
}

Journal of Central Banking Theory and Practice, 2020, 1, pp. 185-218

Received: 25 October 2018; accepted: 18 January 2019

Elhadj Ezzahid *, Brahim Maouhoub **

\section{Capital Account Liberalization in Morocco: Is it Compatible with Fixed or Flexible Exchange Rate Regime?}

UDK: 339.743(64)

DOI: $10.2478 / j c b t p-2020-0010$

\author{
* Mohammed V University, \\ Rabat, Morocco \\ E-mail: \\ ezzahidelhadj@yahoo.fr \\ ${ }^{* *}$ Mohammed V University, \\ Rabat, Morocco \\ E-mail: \\ b.maouhoub@live.com
}

\begin{abstract}
This paper examines the opportunity of exchange rate regime flexibilization in Morocco under the policy of capital account liberalization. Basing on our findings in Ezzahid and Maouhoub (2014), we develop a new theoretical game model with four economic agents, namely: monetary authorities, government, foreign firms and domestic firms. We explore the optimal exchange rate regime for Morocco under new conditions such as the presence of a compensation fund effect, restrictions on capital outflows, etc. Starting with a first simulation based on current economic parameters, the results show that losses under a flexible exchange rate regime are lower than losses under a fixed exchange rate regime. Varying different parameters allow discovering the 'appropriate level' from which monetary authorities should move toward the flexible exchange rate.
\end{abstract}

Keywords: Capital account liberalization, Exchange rate regime flexibilization, compensation fund, Real exchange rate, and game theory.

Jel classification: F31, F32.

\section{Introduction}

The financial liberalization theory predicts that capital account openness allows developing countries to receive international capital flows and to boost investment, and therefore contribute to more efficient allocation of re- 
sources and to more financial development. The confrontation of theoretical predictions and developing countries experiences renews the debate on capital account liberalization effects. Furthermore, to take advantages from capital account liberalization, developing countries adopt various approaches and strategies appropriate to their specific circumstances.

Capital account liberalization is not without risks. International capital flows can bring with them their own problems, such as real exchange rate appreciation and inflation increasing under a fixed exchange rate regime (Corbo and Hernández, 1996). The experiences of Latin America and East Asia give us many lessons about the risk associated with capital account liberalization under a fixed exchange rate regime. The important one is that preparing exchange rate flexibilization in parallel with capital account liberalization is required to ensure exchange rate adjustments. Furthermore, referring to the impossible trinity, it's impossible for an economy to attain simultaneously fixed exchange rate regime, free capital account and autonomy of monetary policy (Mundell, 1963).

It is true that the fixed exchange rate regime ensures economic confidence and policy credibility, stabilizes nominal exchange rate and avoids volatility risks; but, it can result in a misallocation of resources and then in a low economic growth. The explanation is that in countries with fixed exchange rate regime and higher investment, the productivity grows more slowly than in countries with floating exchange rates, because nominal exchange rate is unable to be used as an adjustment mechanism (Ghosh et al. 1996).

The empirical link between the choice of exchange rate regime and economic growth is a controversial debate. Some studies show that less flexible exchange rate regimes are associated with slower growth in developing countries (for example Levy-Yeyati and Sturzenegger, 2003). Meanwhile, other studies indicate the absence of any robust relationship between the choice of exchange rate regime and economic growth in developing countries (for example De Vita and Kyaw, 2011). Moreover, the majority of empirical findings indicate that the positive relationship between monetary policy and growth is stronger in financially developed countries; however, it is weaker in financially underdeveloped countries with weak integration into global markets (Odhiambo and Twinoburyo, 2018).

On the one hand, the exchange rate flexibilization is based on the hypothesis of Friedman (1953) and Mundell (1961), arguing that flexible exchange rates act as a 'shock absorber' in a small open economy. Accordingly, the flexible exchange rate regime is favourable for developing countries because it allows the adjustment process that stabilizes the macroeconomic variables when negative external shocks hit the economy (Hoffmann, 2007). On the other hand, the choice of ex- 
change rate regime for developing countries depends on their policy orientations and on their economic settings rather than on theoretical predictions, empirical studies and economic experiences.

The International Monetary Fund -as part of his annual consultations for developing countries, among them Morocco- recommends more flexibilization of their exchange rate regimes. In this paper, we assess Moroccan experience and the opportunity for Morocco to move toward more flexible exchange rate regime. The point that we seek to determine is the 'appropriate level' - based on Moroccan economic specificities - from which monetary authorities should move to a more flexible exchange rate regime. In other words, we try to determine the optimal exchange rate regime under current economic conditions.

The paper proposes a new theoretical model adapted to the Moroccan context and able to take into account the real exchange rate misalignment, the inflation targeting, the gradual capital account liberalization and the Compensation Fund Effect ${ }^{1}$. Thus, we organize the paper as follows: Section 2 presents the theoretical framework. Section 3 is reserved for the model construction. The parameters are estimated in Section 4. Model simulations and results are discussed in Section 5. The last Section summarizes the concluding remarks.

\section{Theoretical and conceptual framework}

The issue of the exchange rate regime optimality is highly debated by Aizenman (1994), Chin and Miller (1995), Devereux and Engel (2000), etc. An optimal exchange rate regime corresponds to a regime that minimizes risks (currency instability, capital volatility, etc.) and maximizes benefits (policy credibility, economic confidence, economic agent planning, etc.) associated with a given exchange rate regime. Consequently, an optimal exchange rate regime may be a fixed or a flexible regime, all depends on economic conditions and monetary policy objectives.

To model the economic agents' behaviour, we refer to the game theory. The model is represented as a game where monetary authorities make decisions and other economic agents react to these decisions (Figure 1). All economic agents are conscious that their benefits depend not only on their decisions, but also on the reactions of others. To make an optimal decision, monetary authorities have to define their objective function and the objective functions of other economic agents.

\footnotetext{
A Fund created by Moroccan government to subside elementary goods such as liquid petro-
} leum, Butane gas, sugar and national soft wheat flour, in order to stabilize prices. 
Figure 1: Economic agents and different choices in the base model

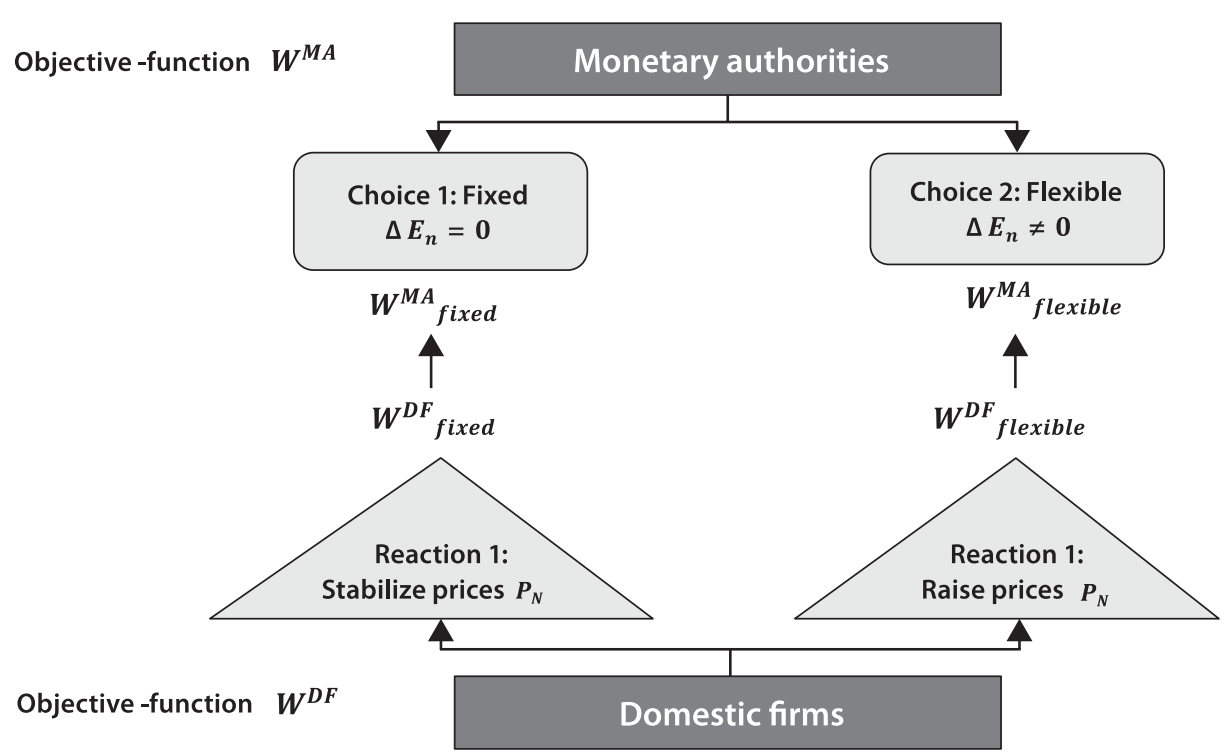

The base model considered in this work - see Ezzahid and Maouhoub (2014) - is based on the framework proposed by Agénor $(1991,1994)$ for developing countries. We consider a small open economy producing tradable and non-tradable goods, where economic agents are monetary authorities and domestic firms interact through an optimization game. Each agent tries to minimize his loss-function using his own instruments: choice of an exchange rate regime for monetary authorities (fixed or flexible) and price fixation for domestic firms (increase or decrease).

Many extended models are simulated for developing and emerging countries. For example Zhang (2001) explored the Chinese case, Ben Ali (2006) explored the Tunisian case, and Ezzahid and Maouhoub (2014) explored the Moroccan case. The aim of these simulations is to determine from which economic level the choice of flexible exchange rate regime becomes an optimal choice for monetary authorities.

\section{Model construction}

The base model does not take into consideration Moroccan economic specificities such as the effect of compensation fund on inflation, the government strategy 
to suppress progressively the compensation fund, foreign firms, capital returns, domestic firms, the presence of restrictions on capital outflows, etc. Introducing these facts in the model may significantly improve the results. For this reason, we construct a new model adapted to Moroccan economic conditions and based on the theoretical framework presented above.

Consider a model of a small open economy (Figure 2) where monetary authorities (MA) have two options: to stay under a fixed exchange rate regime or move to a flexible exchange rate regime. The choice of an optimal exchange rate regime is required in a context of capital account liberalization. To make an optimal choice, monetary authorities must define the objective functions of all economic agents and then determine the variables that impact their decisions: monetary authorities' objective function, government's objective function, domestic firms' objective function and foreign firms' objective function.

Figure 2: Model developed for Morocco, authors' design

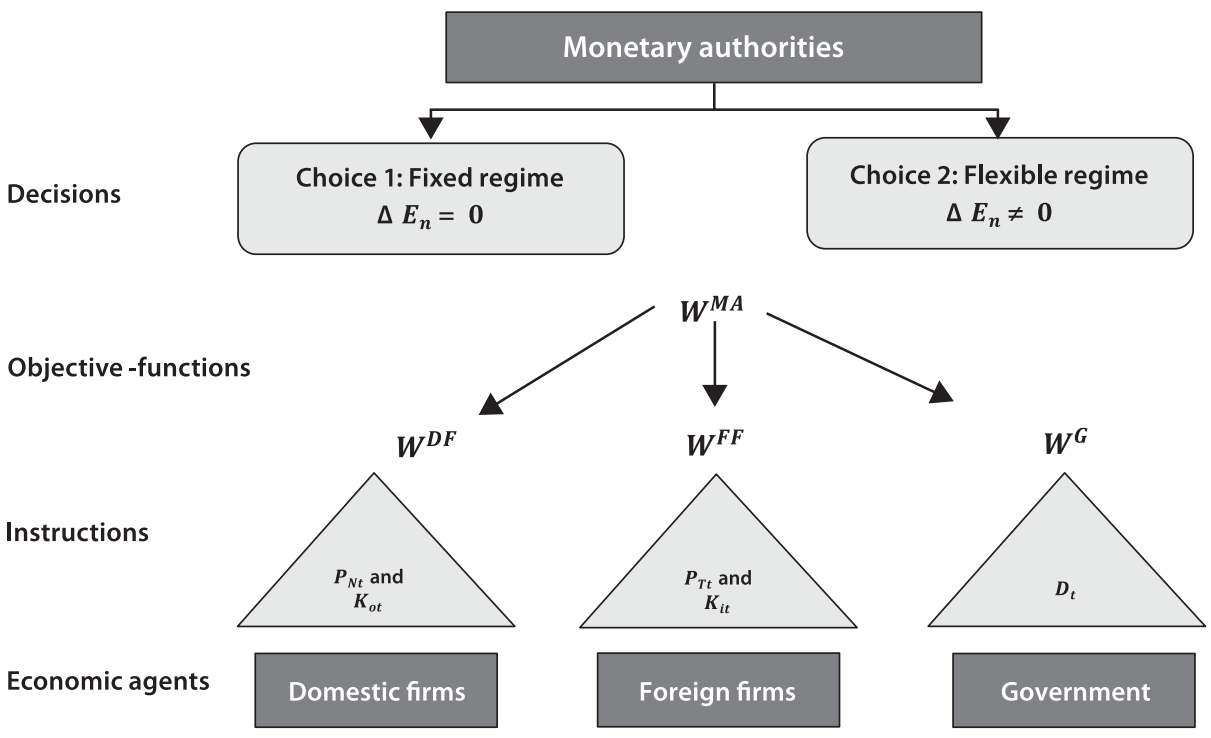

The model developed is based on the following hypothesis:

Hypothesis 1: general price level determination $\left(\boldsymbol{\Pi}_{\boldsymbol{t}}\right)$. The economy is composed of two-sectors: tradable sector and non-tradable sector. The general price level is assumed to be determined as follows:

$\Pi_{t}=\Pi_{\mathrm{Nt}}^{\delta} \cdot\left(\Pi_{\mathrm{Tt}} \cdot \mathrm{E}_{\mathrm{nt}}\right)^{1-\delta}$ 
Where $\boldsymbol{\Pi}_{\mathbf{N t}}$ is the price level of non-tradable goods, $\boldsymbol{\Pi}_{\mathbf{T t}}$ is the price level of tradable goods, $\mathbf{E}_{\mathbf{n t}}$ is the nominal effective exchange rate and $(\mathbf{1}-\boldsymbol{\delta})$ is the economic openness rate. In growth rate terms, the equation (eq.1.1) takes the following expression:

$\pi_{t}=\delta \pi_{\mathrm{Nt}}+(1-\delta)\left(\pi_{\mathrm{Tt}}+e_{n t}\right)$

$\boldsymbol{\pi}_{\mathbf{t}}$ is the inflation rate without compensation fund effect.

Hypothesis 2: tradable prices determination $\Pi_{T t}$ and non-tradable prices determination $\Pi_{\mathbf{N t}}$. The price level of tradables $\boldsymbol{\Pi}_{\mathrm{Tt}}$ is determined in international markets and is assumed to be equal ${ }^{2}$ to the world general price level $\boldsymbol{\Pi}_{\boldsymbol{t}}^{*}$ :

$\Pi_{\mathrm{Tt}}=\Pi_{t}^{*}$

In growth rate terms, the equation (eq. 1.2.1) gives the world inflation rate:

$\boldsymbol{\pi}_{\mathbf{t}}^{*}=\boldsymbol{\pi}_{\mathbf{T t}}$

The price level of non-tradables $\boldsymbol{\Pi}_{\mathbf{N}}$ is domestically determined by the following mechanism:

$\Pi_{\mathrm{Nt}}=\left(\frac{E_{r t}}{E_{r t}^{\circ}}\right)^{\rho} \cdot M_{t}^{v}$

Where $\boldsymbol{E}_{\boldsymbol{r} t}^{0}$ is the equilibrium real effective exchange rate, $\boldsymbol{M}_{\boldsymbol{t}}$ is the money supply, $\boldsymbol{\rho}$ is the elasticity of $\boldsymbol{\Pi}_{\mathbf{N t}}$ to the real exchange rate misalignment and $\boldsymbol{v}$ is the elasticity of $\boldsymbol{\Pi}_{\mathbf{N t}}$ to the money supply. The price level of non-tradable goods $\boldsymbol{\Pi}_{\mathbf{N t}}$ is determined by two factors. The first is the deviation of the real exchange rate from its equilibrium level. A real depreciation increases the external competitiveness of the economy, which increases in the tradable goods demand (i.e. an increase in exports). Therefore, domestic firms shift resources from non-tradable sector to tradable sector. The resources transfer lowers the production of non-tradable goods (i.e. a decrease in supply), which raises their prices. A real exchange rate appreciation produces the opposite effects. In growth rate terms, the equation (eq. 2.1) takes the following expression:

$\pi_{\mathrm{Nt}}=\rho\left(e_{r t}-e_{r t}^{0}\right)+v m_{t}$

2 We suppose that the world general price level is written as follows: $\Pi_{\mathrm{t}}^{*}=\Pi_{\mathrm{Nt}}^{* \mathrm{i}} \Pi_{\mathrm{Tt}}^{1-\mathrm{i}}$ with $\Pi_{\mathrm{Nt}}^{*}$ is the world general price level of non-tradable goods, $\Pi_{\mathrm{Tt}}$ is the world general price level of tradable goods and $1-i$ is the international economic integration. Thus, when international economy is fully interacted: $(1-\mathrm{i})=1$, so $\Pi_{\mathrm{Tt}}=\Pi_{\mathrm{t}}^{*}$. 
Hypothesis 3: compensation fund effect $\left(D_{t}\right)$. The government reduces prices using the Compensation Fund Effect $\boldsymbol{D}_{\boldsymbol{t}}$. We suppose that the price level of tradables and non-tradables are reduced by the following mechanism:

$\mathbf{P}_{\mathrm{Nt}}=\frac{\Pi_{\mathrm{Nt}}}{D_{t}{ }^{a}}$ and $\mathbf{P}_{\mathrm{Tt}}=\frac{\Pi_{\mathrm{Tt}} \cdot \mathbf{E}_{\mathrm{nt}}}{D_{t}{ }^{1-a}}$

(eq. 3.1) and (eq.3.2)

Where $\mathbf{P}_{\mathbf{N t}}$ is the subsided price level of non-tradables, $\mathbf{P}_{\mathbf{T t}}$ is the subsided price level of tradables, $\boldsymbol{D}_{\boldsymbol{t}}$ is the Compensation Fund effect, $\boldsymbol{a}$ is the proportion of compensation fund effect allocated to reduce non-tradable prices and $\mathbf{1}-\boldsymbol{a}$ is the proportion of compensation fund effect allocated to reduce tradable prices.

From (eq. 1.1), (eq.3.1) and (eq.3.2), we write the expression of subsided general price level $\mathbf{P}_{\boldsymbol{t}}$ in function of subsided non-tradable prices $\mathbf{P}_{\mathbf{N t}}$ and of subsided tradable prices $\mathbf{P}_{\mathbf{T t}}$ as follows:

$\mathbf{P}_{t}=\frac{\Pi_{t}}{D_{t}{ }^{a \delta+(1-a)(1-\delta)}}=\left[\frac{\Pi_{\mathrm{Nt}}}{D_{t}{ }^{a}}\right]^{\delta} \cdot\left[\frac{\Pi_{\mathrm{Tt}} \cdot \mathrm{E}_{\mathrm{nt}}}{D_{t}{ }^{1-a}}\right]^{1-\delta}$

Or $\mathbf{P}_{t}=\left[\mathbf{P}_{N t}\right]^{\delta} \cdot\left[\mathbf{P}_{T t} . \mathbf{E}_{\mathbf{n t}}\right]^{1-\delta}$

In growth rate terms, the equations (eq.4.1) and (eq.4.2) give the compensated inflation rate:

$$
\begin{aligned}
& p_{t}=\delta\left[\pi_{\mathrm{Nt}}-\mathbf{a} \cdot d_{t}\right]+(1-\delta)\left[\pi_{\mathrm{Tt}}-(1-a) d_{t}+e_{n t}\right] \\
& \text { Or } \mathbf{p}_{t}=\delta \mathbf{p}_{\mathrm{Nt}}+(1-\delta)\left(\mathbf{p}_{\mathrm{Tt}}+e_{n t}\right) \\
& =\pi_{t}-(a \delta+(1-a)(1-\delta)) d_{t}
\end{aligned}
$$

We can write $\boldsymbol{d}_{\boldsymbol{t}}$ as follows:

$$
\begin{aligned}
& d_{t}=\frac{\pi_{\mathrm{t}}-\mathbf{p}_{t}}{a \delta+(1-a)(1-\delta)} \\
& =\frac{\left[\delta \pi_{\mathrm{Nt}}+(1-\delta)\left(\pi_{\mathrm{Tt}}+e_{n t}\right)\right]-\left[\delta \mathbf{p}_{\mathrm{Nt}}+(1-\delta)\left(\mathbf{p}_{\mathrm{Tt}}+\boldsymbol{e}_{n t}\right)\right]}{a \delta+(1-a)(1-\delta)} \\
& =\frac{\delta}{a \delta+(1-a)(1-\delta)}\left(\pi_{\mathrm{Nt}}-\mathbf{p}_{\mathrm{Nt}}\right)+\frac{(1-\delta)}{a \delta+(1-a)(1-\delta)}\left[\left(\pi_{\mathrm{Tt}}+\boldsymbol{e}_{n t}\right)-\left(\mathbf{p}_{\mathrm{Tt}}+\boldsymbol{e}_{n t}\right)\right] \text { (eq. 6.1) }
\end{aligned}
$$

In order to simply this equation, we pose two expressions:

$\left(\boldsymbol{\pi}_{\mathrm{Nt}}-\mathbf{p}_{\mathrm{Nt}}\right)=\boldsymbol{b} \mathbf{p}_{\mathrm{Nt}}$, where $\boldsymbol{b} \geq \mathbf{0}$ and $\frac{\mathbf{p}_{\mathrm{Nt}}}{\boldsymbol{\pi}_{\mathrm{Nt}}}=\frac{\mathbf{1}}{\mathbf{1 + b}}$ is the ratio of subsided nontradable prices to non-subsided non-tradable prices; 
$\left[\left(\boldsymbol{\pi}_{\mathbf{T t}}+\boldsymbol{e}_{\boldsymbol{n} t}\right)-\left(\mathbf{p}_{\mathbf{T t}}+\boldsymbol{e}_{\boldsymbol{n t}}\right)\right]=\boldsymbol{c}\left(\mathbf{p}_{\mathbf{T t}}+\boldsymbol{e}_{\boldsymbol{n t}}\right)$, where $\boldsymbol{c} \geq \mathbf{0}$ and $\frac{\mathrm{p}_{\mathrm{Tt}}+e_{n t}}{\pi_{\mathrm{Tt}}+e_{n t}}=\frac{1}{1+c}$ is the ratio of subsided tradable prices to subsided non-tradable prices.

The parameters $b$ and $c$ are introduced to measure the extent of compensation fund effect through the gap between non-subsided price level and subsided price level. As a result, (eq. 6.1) becomes:

$d_{t}=\frac{\delta b}{a \delta+(1-a)(1-\delta)} \mathbf{p}_{\mathrm{Nt}}+\frac{(1-\delta) c}{a \delta+(1-a)(1-\delta)}\left(\mathbf{p}_{\mathrm{Tt}}+e_{n t}\right)$

We consider the equation (eq. 6.2) as the government's function reaction.

Hypothesis 4: real effective exchange rate definition. We adopt the following definition for the real effective exchange rate:

$E_{r t}=\frac{E_{n t} \cdot P_{T t}}{P_{N t}}$

Where $E_{n t}$ is the nominal effective exchange rate. In growth rate terms, the equation (eq. 7.1) takes the following expression:

$e_{r t}=e_{n t}+p_{T t}-p_{N t}$

Hypothesis 5: capital account restrictions. We denote capital inflows by $\boldsymbol{K}_{\boldsymbol{i t}}$ and capital outflows by $\boldsymbol{K}_{\boldsymbol{o t}}$. Moroccan monetary authorities impose restrictions on capital outflows $\boldsymbol{K}_{\boldsymbol{o t}}$ to avoid any situation of capital flight. Nevertheless, monetary authorities don't impose any restrictions on capital inflows $\boldsymbol{K}_{\boldsymbol{i t}}$ and they look for higher capital inflows. However, we suppose that capital inflows must not exceed domestic financial requirement in order to avoid any capital influx.

We define the capital account ${ }^{3}$ as follows:

$K A_{t}=K_{i t} * E_{n t}-K_{o t}$

We suppose that restrictions on capital outflows $\boldsymbol{K}_{\boldsymbol{o t}}$ are imposed as follows:

$K_{o t}^{n}=K_{i t} * E_{n t}$

Where $n \in \mathbb{R}^{*+}$ is a restriction on capital outflows. In other words, the amount of capital authorized to outflow is:

3 Capital outflows $\mathrm{K}_{\mathrm{ot}}$ are in Moroccan dirhams and capital inflows are $\mathrm{K}_{\mathrm{it}}$ are in foreign currencies. 
$K_{o t}=\left(K_{i t} * E_{n t}\right)^{\frac{1}{n}}$

This means that the amount of capital outflows $\boldsymbol{K}_{\boldsymbol{o t}}$ cannot exceed $\left(\boldsymbol{K}_{\boldsymbol{i t}} * \boldsymbol{E}_{\boldsymbol{n} t}\right)^{\frac{1}{n}}$.

Hypothesis 6: domestic firms, foreign firms and investment decision process. We suppose that domestic firms invest their capital into foreign markets in function of real return $\boldsymbol{R}_{\boldsymbol{o t}}$ resulting from capital invested abroad:

$\boldsymbol{R}_{\boldsymbol{o t}}=\frac{\left(\frac{K_{o t}}{E_{n t}}\right) \cdot \Gamma_{t}^{*} \cdot I_{t}^{*}}{\Pi_{t}^{*}}$

Where $\left(\mathbf{1}-\Gamma_{t}^{*}\right)$ is the international capital depreciation rate, $\boldsymbol{I}_{t}^{*}$ is the international real interest rate, $\boldsymbol{\Pi}_{t}^{*}$ is the international general price level. In growth rate terms, the equation (9.1) takes the following expression:

$\mathbf{r}_{\mathrm{ot}}=\left(\mathbf{k}_{\mathrm{ot}}-\mathbf{e}_{\mathrm{nt}}\right)+\gamma_{t}^{*}+\mathbf{i}_{t}^{*}-\boldsymbol{\pi}_{t}^{*}$

We suppose that domestic firms' investment in foreign markets is elastic to capital real return as follows:

$\boldsymbol{K}_{o t}=\left(\boldsymbol{R}_{o t}\right)^{\phi}$

Where $\boldsymbol{\phi}$ is the elasticity of capital outflows $\boldsymbol{K}_{\boldsymbol{o t}}$ to real return $\boldsymbol{R}_{\boldsymbol{o t}}$. In growth rate terms, the equation (eq. 9.3) takes the following expression:

$\boldsymbol{k}_{o t}=\phi \mathrm{r}_{\mathrm{ot}}$

We suppose also that foreign firms invest a part of their capital $\boldsymbol{K}_{\boldsymbol{i t}}$ in Morocco generating the following real return $\boldsymbol{R}_{\boldsymbol{i t}}$ :

$\boldsymbol{R}_{i t}=\frac{\left(\boldsymbol{K}_{i t} \cdot \boldsymbol{E}_{n t}\right) \cdot \Gamma_{t} \cdot \mathbf{I}_{t}}{\boldsymbol{P}_{t}}$

Where $\mathbf{1}-\boldsymbol{\Gamma}_{\boldsymbol{t}}$ is the domestic capital depreciation rate, $\mathbf{I}_{\boldsymbol{t}}$ is the domestic interest rate and $\boldsymbol{P}_{\boldsymbol{t}}$ is the subsided general price level. In growth rate terms, the equation (eq. 10.1) takes the following expression:

$r_{i t}=\left(k_{i t}+e_{n t}\right)+\gamma_{t}+i_{t}-p_{t}$

We suppose that their investment in Morocco is elastic to real return as follows:

$$
K_{i t}=\left(R_{i t}\right)^{\varphi}
$$


Where $\boldsymbol{\varphi}$ is the elasticity of capital inflows $\boldsymbol{K}_{\boldsymbol{i t}}$ to real return $\boldsymbol{R}_{\boldsymbol{i t}}$. In growth rate terms, the equation (eq. 10.3) takes the following expression:

$\boldsymbol{k}_{i t}=\varphi \mathrm{r}_{\mathrm{it}}$

Under this hypothesis, the Moroccan monetary authorities define their objective function and take into consideration the objective functions of all other economic agents.

Monetary authorities' objective function. Monetary authorities try to affect indirectly the economic performances through exchange rate regime, inflation targeting and capital flows restrictions. Therefore, monetary authorities are concerned only with the decisions of economic agents and the transmission of different channels (Aguir, 2018).

We denote monetary authorities' objective function $\boldsymbol{W}_{\boldsymbol{t}}^{\boldsymbol{M} \boldsymbol{A}}$ and we define their objectives as follows:

The first objective is to avoid the misalignment of real effective exchange rate $\boldsymbol{E}_{\boldsymbol{r}}$ from its equilibrium level $\boldsymbol{E}_{\boldsymbol{r} \boldsymbol{t}}^{0}$. As a result, $\boldsymbol{E}_{\boldsymbol{r} \boldsymbol{t}}>\boldsymbol{E}_{\boldsymbol{r} \boldsymbol{t}}^{\circ}$ signifies that real effective exchange rate is depreciated and $\boldsymbol{E}_{\boldsymbol{r} \boldsymbol{t}}<\boldsymbol{E}_{\boldsymbol{r} \boldsymbol{t}}^{\circ}$ signifies that real effective exchange rate is appreciated. Monetary authorities try to conserve the equality $\frac{\boldsymbol{E}_{r t}}{\boldsymbol{E}_{r t}^{\circ}}=\mathbf{1}$ or in growth rate terms, the equality $\boldsymbol{e}_{\boldsymbol{r} t}-\boldsymbol{e}_{\boldsymbol{r} \boldsymbol{t}}^{0}=\mathbf{0}$. This means for the Central Bank to minimize the quantity ${ }^{4}$ :

$\frac{1}{2}\left(e_{r t}-e_{r t}^{0}\right)^{2}$

The second objective is to stabilize the inflation rate $\boldsymbol{p}_{\boldsymbol{t}}$ with respect to target inflation rate $\boldsymbol{p}_{\boldsymbol{t}}$, this requires to conserve the equality $\boldsymbol{p}_{\boldsymbol{t}}-\boldsymbol{p}_{\boldsymbol{t}}^{0}=\mathbf{0}$. Therefore, the Central Bank minimizes the following quantity to avoid any situation of high inflation $\boldsymbol{p}_{\boldsymbol{t}}>\boldsymbol{p}_{\boldsymbol{t}}^{\circ}$ or low inflation $\boldsymbol{p}_{\boldsymbol{t}}<\boldsymbol{p}_{\boldsymbol{t}}^{\circ}$ :

$\frac{1}{2}\left(p_{t}-p_{t}^{0}\right)^{2}$

The third objective is to preserve the capital account equilibrium i.e. to preserve the equality $\frac{\boldsymbol{K}_{\boldsymbol{i t}} \boldsymbol{E}_{\boldsymbol{n} \boldsymbol{t}}}{\boldsymbol{K}_{\boldsymbol{o t}}^{\boldsymbol{t}}}=\mathbf{1}$, or in growth rate terms the equality $\left(\boldsymbol{k}_{\boldsymbol{i t}}+\boldsymbol{e}_{\boldsymbol{n} \boldsymbol{t}}\right)-\boldsymbol{n} \boldsymbol{k}_{\boldsymbol{o t}}=\mathbf{0}$. In other words, monetary authorities have to minimize the following quantity:

\footnotetext{
4 We use the square to explain that any deviation of real effective exchange rate from its equilibrium is transformed to a loss for the Central Bank. We add also $1 / 2$ to eliminate square after derivation.
} 
$\frac{1}{2}\left[\left(k_{i t}+e_{n t}\right)-n k_{o t}\right]^{2}$

From (Exp. A), (Exp. B) and (Exp. C), we can construct the monetary authorities' objective function:

$W_{t}^{M A}=\frac{1}{2} \alpha\left(e_{r t}-e_{r t}^{\circ}\right)^{2}+\frac{1}{2} \cdot \beta\left(p_{t}-p_{t}^{\circ}\right)^{2}+\frac{1}{2} \vartheta\left[\left(k_{i t}+e_{n t}\right)-n k_{o t}\right]^{2}$ (eq. 10)

Where $\boldsymbol{\alpha}$ is the weight granted by monetary authorities to real exchange rate misalignment, $\boldsymbol{\beta}$ is the weight granted by monetary authorities to inflation and $\boldsymbol{\vartheta}$ is the weight granted by monetary authorities to capital account restrictions $(\boldsymbol{\vartheta}=\mathbf{1}-\boldsymbol{\alpha}-\boldsymbol{\beta})$. Monetary authorities have to evaluate their objective function $\boldsymbol{W}_{\boldsymbol{t}}^{\boldsymbol{M} \boldsymbol{A}}$ under the fixed and the flexible exchange rate regimes.

Government' objective function. The Moroccan Government (as the fiscal authority) tries to reduce the budget deficit by reducing the Compensation Fund. Consequently, the Compensation Fund Effect $\boldsymbol{D}_{\boldsymbol{t}}$ must be reduced to equalize the Target Compensation Fund Effect $\boldsymbol{D}_{\boldsymbol{t}}^{\circ}$. Thus, the government tries to preserve the equality $\frac{D_{t}}{D_{t}^{\circ}}=\mathbf{1}$, or in growth rate terms the equality $\boldsymbol{d}_{t}-\boldsymbol{d}_{t}^{\circ}=\mathbf{0}$. As a result, $\boldsymbol{d}_{\boldsymbol{t}}>\boldsymbol{d}_{\boldsymbol{t}}^{\circ}$ signifies that high public spending on the compensation fund will increase the budget deficit, and $\boldsymbol{d}_{\boldsymbol{t}}<\boldsymbol{d}_{\boldsymbol{t}}^{\circ}$ signifies that less public spending on the compensation fund will damage the purchasing power and disturb the social harmony. Accordingly, the government has to minimize the following objective function:

$W_{t}^{G}=\frac{1}{2}\left(d_{t}-d_{t}^{\circ}\right)^{2}$

Comparing the budget deficit including compensation expenditures with the budget deficit excluding compensation expenditures (Graphic 1), shows clearly that the origin of the Moroccan budget deficit is the compensation fund.

Domestic firms' objective function. Domestic firms take into consideration the authorized capital to invest abroad $\boldsymbol{K}_{\boldsymbol{o t}}^{\circ}$. They try to maximize their real return and to preserve the equality $\frac{\boldsymbol{K}_{\boldsymbol{o t}}}{\boldsymbol{K}_{\boldsymbol{o}}^{\circ}}=\mathbf{1}$ or in growth rate terms the equality $\boldsymbol{k}_{\boldsymbol{o t}}-\boldsymbol{k}_{\boldsymbol{o t}}^{\circ}=\mathbf{0}$. Thus, their objective is to minimize the following quantity:

$\frac{1}{2}\left[\boldsymbol{k}_{o t}-\boldsymbol{k}_{o t}^{\circ}\right]^{2}$

Moreover, domestic firms produce tradable and non-tradable goods and command only the price of non-tradables $\boldsymbol{\Pi}_{\mathbf{N t}}$. The welfare of domestic firms is also defined in terms non-tradable relative prices. It means that domestic firms react by changing $\boldsymbol{\Pi}_{\mathbf{N t}}$. Indeed, domestic firms attempt to protect themselves by adjust- 
ing continuously the price of non-tradable goods $\boldsymbol{\Pi}_{\mathbf{N t}}$ to the expected level $\boldsymbol{\Pi}_{\boldsymbol{N} \boldsymbol{t}}^{\circ}$ Consequently, they try to preserve the equality $\frac{\Pi_{N t}}{\Pi_{N t}^{o}}=\mathbf{1}$, or in growth rate terms the equality $\boldsymbol{\pi}_{\boldsymbol{N} \boldsymbol{t}}-\boldsymbol{\pi}_{\boldsymbol{N} \boldsymbol{t}}=\mathbf{0}$. They have to minimize the following quantity:

$\frac{1}{2}\left(\pi_{N t}-\pi_{N t}^{\circ}\right)^{2}$

From (Exp. A.1) and (Exp. B.1), we write the domestic firms' objective function as follows:

$W_{t}^{D F}=\frac{1}{2} \mu\left(k_{o t}-k_{o t}^{\circ}\right)^{2}+\frac{1}{2} \tau\left(\pi_{N t}-\pi_{N t}^{\circ}\right)^{2}$

Where $\mu$ is the weight granted by domestic firms to their investment in foreign markets and $\tau$ is the weight granted by domestic firms to non-tradable prices.

Foreign firms' objective function. Foreign firms take into consideration the domestic financial requirement $\boldsymbol{K}_{\boldsymbol{i t}}^{\circ}$. As a result, they look for a maximum real return $\boldsymbol{R}_{\boldsymbol{i t}}$ under the constraint of $\boldsymbol{K}_{\boldsymbol{i t}}^{\circ}$. They try to maximize their real return and preserve the equality $\frac{\boldsymbol{K}_{\boldsymbol{i t}}}{\boldsymbol{K}_{\boldsymbol{i t}}^{\circ}}=\mathbf{1}$, or in growth rate terms the equality $\boldsymbol{k}_{\boldsymbol{i t}}-\boldsymbol{k}_{\boldsymbol{i t}}^{\circ}=\mathbf{0}$. Their objective is to minimize the following objective function:

$W_{t}^{F F}=\frac{1}{2}\left(k_{i t}-k_{i t}^{0}\right)^{2}$

Exchange rate regime choice. The economic problem for monetary authorities is to adopt the adequate exchange rate regime that minimizes their objective function. We have four objective functions summarized as follows:

$W_{t}^{M A}=\frac{1}{2} \alpha\left(e_{r t}-e_{r t}^{\circ}\right)^{2}+\frac{1}{2} \cdot \beta\left(p_{t}-p_{t}^{\circ}\right)^{2}+\frac{1}{2} \vartheta\left[\left(k_{i t}+e_{n t}\right)-n k_{o t}\right]^{2}$ (eq. 11)

$W^{G}=\frac{1}{2}\left(d_{t}-d_{t}^{\circ}\right)$

$W_{t}^{D F}=\frac{1}{2} \mu\left(k_{o t}-k_{o t}^{\circ}\right)^{2}+\frac{1}{2} \tau\left(\pi_{\mathrm{Nt}}-\pi_{\mathrm{Nt}}^{\circ}\right)^{2}$

$W_{t}^{F F}=\frac{1}{2}\left(k_{i t}-k_{i t}^{\circ}\right)^{2}$

First, we replace variables with their expressions as follows:

$$
\left\{\begin{array}{c}
W_{t}^{M A}=\frac{1}{2} \alpha\left[e_{n t}+\pi_{\mathrm{Tt}}-(1-a) d_{t}-\pi_{\mathrm{Nt}}+a d_{t}-e_{r t}^{\circ}\right]^{2}+\frac{1}{2} \cdot \beta\left[\delta\left(\pi_{\mathrm{Nt}}-a d_{t}\right)+(1-\delta)\left(\pi_{\mathrm{Tt}}+e_{n t}-(1-a) d_{t}\right)-p_{t}^{\circ}\right]^{2}+\frac{1}{2} \vartheta\left[k_{i t}+e_{n t}-n k_{o t}\right]^{2} \\
W_{t}^{G}=\frac{1}{2}\left[\frac{\delta b}{a \delta+(1-a)(1-\delta)}\left(\pi_{\mathrm{Nt}}-a d_{t}\right)+\frac{c(1-\delta)}{a \delta+(1-a)(1-\delta)}\left[\pi_{\mathrm{Tt}}+e_{n t}-(1-a) d_{t}\right]-d_{t}^{\circ}\right]^{2} \\
W_{t}^{D F}=\frac{1}{2} \mu\left[\phi\left[\left(\mathrm{k}_{\mathrm{ot}}-\mathrm{e}_{\mathrm{nt}}\right)+\gamma_{t}^{*}+\mathrm{i}_{t}^{*}-\pi_{\mathrm{Tt}}\right]-k_{o t}^{\circ}\right]^{2}+\frac{1}{2} \tau\left[\rho\left(e_{n t}+\pi_{\mathrm{Tt}}-(1-a) d_{t}-\pi_{\mathrm{Nt}}+a d_{t}-e_{r t}^{\circ}\right)+v m_{t}-\pi_{N t}^{\circ}\right]^{2} \\
W_{t}^{F F}=\frac{1}{2}\left[\varphi\left[\left(k_{i t}+e_{n t}\right)+\gamma_{\mathrm{t}}+\mathrm{i}_{\mathrm{t}}-\delta\left(\pi_{\mathrm{Nt}}-a d_{t}\right)-(1-\delta)\left(\pi_{\mathrm{Tt}}-(1-a) d_{t}+e_{n t}\right)\right]-k_{i t}^{o}\right]^{2}
\end{array}\right.
$$


Second, variables of interest of economic agents (government, domestic firms, foreign firms) are equal to the target levels at the equilibrium $\boldsymbol{d}_{\boldsymbol{t}}=\boldsymbol{d}_{\boldsymbol{t}}, \boldsymbol{k}_{\boldsymbol{o t}}=\boldsymbol{k}_{\boldsymbol{o t}}^{0}$, $\boldsymbol{\pi}_{\mathbf{N t}}=\boldsymbol{\pi}_{\mathbf{N t}}^{\circ}$ and $\boldsymbol{k}_{\boldsymbol{i t}}=\boldsymbol{k}_{\boldsymbol{i} \boldsymbol{t}}^{\circ}$. The model takes the following form under the fixed exchange regime $\left(\mathbf{e}_{\mathbf{n t}}=\mathbf{0}\right)$ :



And it takes the following form under the flexible exchange regime $\left(\boldsymbol{e}_{\boldsymbol{n} \boldsymbol{t}} \neq \mathbf{0}\right)$ :

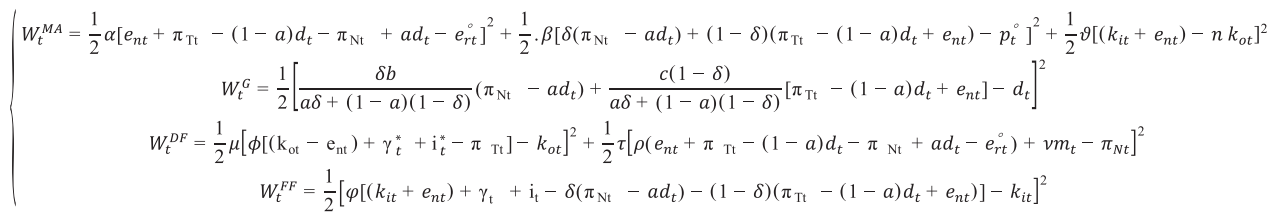

The model minimization and resolution - under the fixed exchange rate regime and under the flexible exchange rate regime- are solved using MATLAB.

\section{Estimation of model parameters}

The model parameters are estimated as follows:

Monetary authorities and domestic firms' preferences $(\boldsymbol{\alpha}, \boldsymbol{\beta}, \boldsymbol{\vartheta}, \boldsymbol{\mu}$ and $\tau)$. According to Bank Al-Maghreb, the prior objective of monetary policy is the price stabilizing, which is considered as a determinant factor to ensure the investment climate and the economic growth, and to protect the domestic purchasing power ${ }^{5}$. As well, to improve the external economic competitiveness, monetary authorities avoid real exchange rate misalignment. The capital account is introduced to quantify the effect of capital account liberalization in terms of inflation and of competitiveness.

As Latin American and Asian experiences show, capital inflows to developing countries raise the inflation and appreciate the real exchange rate. The theoretical mechanism is explained as follows: capital inflows to developing countries

5 Bank Al-Maghreb, Department of Communication, la Note d'information $\mathrm{N}^{\circ}$ 1- July 2006. 
raise the foreign exchange reserves and expand the money supply, which raises the inflation, appreciates the real exchange rate, and undermines the external competitiveness under a fixed exchange rate regime.

Consequently, we consider the inflation targeting as the most important objective, the external competitiveness (avoiding real exchange rate misalignment) as the second important objective, and the capital account liberalization as the third important objective. We suppose that the weight of inflation targeting is twofold the weight of real misalignment, and that the weight of real misalignment is twofold the weight of capital account liberalization:

$\left\{\begin{array}{c}\alpha+\beta+\vartheta=1 \\ \beta=2 \alpha \\ \alpha=2 \vartheta\end{array}\right.$

The system resolution gives the following values: $\alpha=2 / 7, \beta=4 / 7$ and $\vartheta=1 / 7$.

In Morocco, there is high demand from domestic firms (also from households that we supposed included in domestic firms' objective function) to invest in foreign capital markets. For Moroccan domestic firms, the objective of non-tradable prices adjustment is not certainly the major problem comparing to importance of investment in foreign capital markets. Consequently, we can suppose that the importance to invest in foreign markets is twofold the importance to adjust nontradable prices:

$\left\{\begin{array}{c}\mu+\tau=1 \\ \mu=2 \tau\end{array}\right.$

The system resolution gives the following values: $\mu=\frac{2}{3}$ and $\tau=\frac{1}{3}$.

Equilibrium real effective exchange rate growth $\mathbf{e}_{\mathbf{r t}}^{\circ}$ Using the Stock Flow Approach and the Auto Regressive Distributed Lag (ARDL) methodology, the equilibrium real effective exchange rate is growing between - 0.03 and 0.2 (Graphic 2). We select the mean value of equilibrium real effective exchange rate growth $\mathrm{e}_{\mathrm{rt}}^{\circ}=-0.01917$ over the period 1999-2011, and then we change it in the interval $[-0.03 ; 0.0]$ to test its effect on monetary authorities' objective function.

Target inflation rate $\mathbf{p}_{\mathrm{t}}^{\circ}$. The target level of inflation rate doesn't vary over time. Generally, the central banks fix the percentage of $2 \%$ as a targeted inflation rate: $\mathrm{p}_{\mathrm{t}}^{\circ}=0.02$

Proportions of compensation fund effect allocated to reduce non-tradable prices $\boldsymbol{a}$ and to reduce tradable prices $1-\boldsymbol{a}$. If $\boldsymbol{a}=1$, so the Compensation 
Fund Effect is totally allocated to reduce non-tradable prices. And vice-versa, if $a=0$, so the Compensation Fund Effect is totally allocated to reduce tradable prices. We select the value of $a=0.5$ for first simulation, and we vary it from 0 to 1 to test its effect on the choice of exchange rate regime.

Money supply growth $\mathbf{m}_{\mathbf{t}}$. Money supply is measured by the large aggregate used by Moroccan central Bank (M3). Money supply growth varies between 0.04 and 0.18 with a downward tendency (Graphic 3 ). We select the mean of recent values $\mathrm{m}_{\mathrm{t}}=0.0509$ and we vary it to test its effect on monetary authorities' objective function.

Capital depreciation growth $\boldsymbol{\gamma}_{\mathrm{t}}$ and $\boldsymbol{\gamma}_{\mathrm{t}}^{*}$. The domestic capital depreciation rate is 0.06 (calculated for African countries ${ }^{6}$ ) and the international capital depreciation rate is 0.046 (calculated for Euro zone ${ }^{7}$ ). However, the capital depreciation rates are stable and their growth rate are equal to zero: $\gamma_{\mathrm{t}}=0$ and $\gamma_{\mathrm{t}}^{*}=0$.

Interest rate growth $\mathbf{i}_{\mathbf{t}}$ and $\mathbf{i}_{\mathbf{t}}^{*}$. Moroccan Central Bank decreases the interest rate periodically. The domestic interest rate (Graphic 4) is reduced from $7 \%$ (in 1996 ) to $2.25 \%$ (in 2016). We retain the mean annual growth rate observed for the period 2009-2016: $\mathrm{i}_{t}=-5.37 \%$ for first simulation and we vary it afterward. For international interest rate, we take the U.S. interest rate (Graphic 5) as the World interest rate $\mathrm{I}_{t}^{*}$ and we retain the mean annual growth rate of the same period above 2009-2016: $i_{t}^{*}=-6.88 \%$. This indicates that the world interest rate decreases more rapidly than domestic interest rate.

Capital account restrictions $\boldsymbol{n}$. Restrictions on capital outflows are estimated according to the following approximation:

$n=\frac{\left(k_{i t}+e_{n t}\right)}{k_{o t}}=\frac{k_{i t}}{\left(k_{o t}-e_{n t}\right)}=\frac{\ln (F D I, \text { net inflows }(\text { BoP, current US }))}{\ln (F D I, \text { net outflows }(\text { BoP, current US } \$))}$

The value of elasticity $\boldsymbol{n}$ turns around 1.1 over the recent period of 2003-2015 (Graphic 6).

Elasticities of non-tradable prices to real misalignment $\boldsymbol{\rho}$ and to money supply $\boldsymbol{v}$. The elasticities of non-tradable prices to the real misalignment $\boldsymbol{\rho}$ and to the domestic money supply $v$ are difficult to estimate. We retain the estimated values

6 Rapport Économique sur l'Afrique (2010), élaboré par la Commission Economique pour l'Afrique, p. 134.

7 Monthly Bulletin of European Central Bank (2006), p. 46 
for the Tunisian case (See Ben Ali, 2006), which shows some similarities with respect to Moroccan economy: $\boldsymbol{\rho}=\mathbf{0 . 4}$ and $\boldsymbol{v}=\mathbf{0 . 6}$.

The parameters $\mathbf{b}$ and $\mathbf{c}$. The ratio $\frac{\mathbf{p}_{\mathrm{Nt}}}{\boldsymbol{\pi}_{\mathrm{Nt}}}=\frac{\mathbf{1}}{\mathbf{1}+\boldsymbol{b}}$ may vary from 0 to 1 . Thus, when $\frac{\mathbf{1}}{\mathbf{1}+\boldsymbol{b}} \rightarrow \mathbf{1}$ this means that $\mathbf{p}_{\mathrm{Nt}} \rightarrow \boldsymbol{\pi}_{\mathrm{Nt}}$ and $\boldsymbol{b} \rightarrow \mathbf{0}$ and when $\frac{\mathbf{1}}{\mathbf{1}+\boldsymbol{b}} \rightarrow \mathbf{0}$ this means that $\boldsymbol{\pi}_{\mathbf{N t}} \gg \mathbf{p}_{\mathbf{N t}}$ and $\boldsymbol{b} \rightarrow \infty$. Similarly, the ratio $\frac{\left(\mathbf{p}_{\mathbf{T t}}+\boldsymbol{e}_{n t}\right)}{\left(\boldsymbol{\pi}_{\mathbf{T t}}+\boldsymbol{e}_{n t}\right)}=\frac{\mathbf{1}}{\mathbf{1}+\boldsymbol{c}}$ may vary from 0 to 1 . Thus, when $\frac{1}{1+c} \rightarrow \mathbf{1}$ this means that $\left(\boldsymbol{\pi}_{\mathrm{Tt}}+\boldsymbol{e}_{\boldsymbol{n} t}\right) \rightarrow\left(\mathbf{p}_{\mathrm{Tt}}+\boldsymbol{e}_{\boldsymbol{n} t}\right)$ and $\boldsymbol{c} \rightarrow \mathbf{0}$, and when $\frac{1}{1+\boldsymbol{c}} \rightarrow \mathbf{0}$ this means that $\boldsymbol{\pi}_{\mathrm{Tt}}+\boldsymbol{e}_{\boldsymbol{n} \boldsymbol{t}} \gg \mathbf{p}_{\mathrm{Tt}}+\boldsymbol{e}_{\boldsymbol{n} \boldsymbol{t}}$ and $\boldsymbol{c} \rightarrow \infty$. Because of the estimation difficulty to obtain these parameters, we start the simulation with the following assumed values: $b=\frac{1}{3}$ and $c=\frac{1}{4}$. In order to test their robustness, we vary these parameters in the interval of $[0 ; 3]$.

Economic openness rate $(\mathbf{1}-\boldsymbol{\delta})$ : The economic openness rate is measured by the sum of Imports and Exports divided by Gross Domestic Product. We start the first simulation with the value $\delta=0.3$ (i.e. Moroccan economy is open at $70 \%)$.

Elasticities of capital outflows $\phi$ and of capital outflows $\varphi$ to real returns. The calculation of $\phi$ and $\varphi$ is approximated as follows:

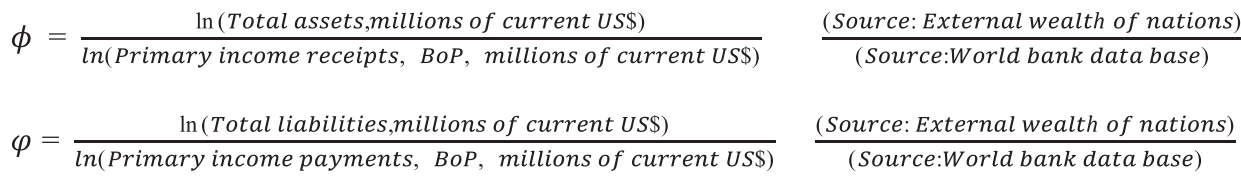

$\varphi$ varies between 1.39 to 1.53 and turns around a mean of 1.45 , and $\phi$ varies between 1.50 and 2.74 and turns around a mean of 1.83 (Graphic 7). We remark that the value of $\phi$ tends to the value of $\varphi$ from 1985 to 2011 . We select the following values: $\varphi=1.45$ and $\phi=1.83$ for first simulation.

Inflation of tradable goods $\boldsymbol{\pi}_{\mathrm{Tt}}$. We consider the inflation rate in EU (major trading partner of Morocco) as the inflation of tradable goods (Graphic 8). The inflation is very low over the recent period of 2013-2015. We select the value of $1 \%: \pi_{t}^{*}=\pi_{\mathbf{T t}}=\mathbf{0 . 0 1}$.

\section{Simulations and discussions}

The recapitulation of estimated and approximated values and of interval of their variations is summarized in Table $\mathbf{1}$. First, we perform the first simulation basing 
on the selected values to know which exchange rate regime is currently the optimal choice for Moroccan monetary authorities. Second, we vary each parameter according to the interval of variation in order to compare monetary authorities' objective function under both fixed and flexible exchange rate regimes.

\section{Simulation based on selected values}

The simulation of monetary authorities' objective function (Table 2) shows that monetary authorities' losses under the fixed exchange rate regime $(0.006855)$ are relatively higher than losses under the flexible exchange rate regime (0.006280). The exchange rate flexibilization reduces monetary authorities' losses by $9.16 \%$.

The desegregation of monetary authorities' losses (Table 3) shows that, under the fixed exchange rate regime, $70.20 \%$ of monetary authorities' losses results from real misalignment, $9.20 \%$ from inflation deviation and $20.60 \%$ from capital account disequilibrium, and that; under the flexible exchange rate regime, 51.99\% of monetary authorities' losses results from real misalignment, 9.46\% from inflation deviation and $38.55 \%$ from capital account disequilibrium. The desegregation shows that the choice of the flexible exchange rate regime reduces losses relative to real misalignment by $-25.94 \%$; but, increases relatively the losses relative to inflation by $+2.76 \%$ and consequently the losses relative to capital account by $+87.16 \%$.

The exchange rate regime flexibilization allows monetary authorities to avoid the real exchange rate misalignment and then to preserve the external economic competitiveness. The mechanism is that under the flexible exchange rate regime, the exchange rate adjusts in nominal terms rather than in real terms. The exchange rate regime flexibilization moderately affects inflation because of the compensation fund effect adjustment. However, the nominal exchange rate adjustment is not without risks. As determined in the model, under the flexible exchange rate regime, the nominal exchange rate ${ }^{8}$ grows by $e_{n t}=1.26 \%$. It is interpreted as a nominal depreciation.

Consequently, under unchanged capital account restrictions $(\mathrm{n}=1.1)$, capital inflows grow more rapidly $\left(\mathrm{k}_{\mathrm{it}}=17.37 \%\right.$ under fixed exchange rate regime and $\mathrm{k}_{\mathrm{it}}=20.97 \%$ under flexible exchange rate regime) than capital outflows $\left(\mathrm{k}_{\mathrm{ot}}=3.01 \%\right.$ under fixed exchange rate regime and $\mathrm{k}_{\mathrm{ot}}=3.48 \%$ under flexible

\footnotetext{
8 The equilibrium nominal exchange rate resulted from model resolution.
} 
exchange rate regime). This is why losses relative to capital account under the flexible exchange rate becomes higher.

\section{Varying capital account restrictions}

We vary the parameter $n$ (Table 4) to show how more capital account liberalization reduces monetary authorities' losses under the flexible exchange rate regime and raises them under the fixed exchange rate regime. The flexible exchange rate choice remains the optimal choice as long as the parameter of capital account restrictions is $0.90<\mathrm{n}<1.25$. The minimal monetary authorities' losses $(0.006173)$ is reached under the flexible exchange rate regime when $n=1.04$ (Graphic 9). As a result, allowing more capital to outflow with respect to capital inflows (decreasing $n$ from 1.10 to 1.04 ) is compatible with the choice of the flexible exchange rate regime.

In cases of massive capital flight $(\mathrm{n} \leq 0.90)$ and massive capital influx $(\mathrm{n} \geq 1.25)$ , the fixed exchange rate becomes an optimal choice, because of high monetary authorities' losses under the flexible exchange rate. The desegregation of monetary authorities' objective function under flexible exchange rate regime shows the losses' structure (Graphic 10). The monetary authorities' losses under the flexible exchange rate regime results from capital account disequilibrium in case of capital flight (high capital account deficits), and from real misalignment in case of capital influx (high real exchange rate appreciation).

\section{Varying monetary authorities' preferences}

The parameters $\alpha, \beta$ and $\vartheta$ play a crucial role in the exchange rate regime choice. The results change by classing the order of importance of parameters according to six possibilities (Table 5). If the monetary authorities consider the real exchange rate misalignment as the most (least) important objective or when they consider the capital account equilibrium as the least (most) important objective, the flexible (fixed) exchange rate come to be the optimal exchange rate regime.

\section{Varying Domestic firms' preferences}

Varying domestic firms' preferences has no effect on monetary authorities' objective function under both fixed and flexible exchange rate. Regardless the order of importance of domestic firms' preferences, the flexible exchange rate remains the optimal choice of monetary authorities. 


\section{Varying economic openness rate}

Increasing the economic openness rate from $50 \%$ to $80 \%$ decreases monetary authorities' losses under both fixed and flexible exchange rate regimes; however, the flexible exchange rate regime remains the optimal choice (Table 6).

\section{Varying compensation fund repartition}

The compensation fund repartition between tradables and non tradables (Table 7) has a significant effect on monetary authorities' choices. As long as $a<0.9$, the flexible exchange rate regime remains the optimal choice for Moroccan monetary authorities. At the moment when $a=0.9$, monetary authorities' losses under the fixed exchange rate regime become equal to losses under the flexible exchange rate. Exceeding the limit $a>0.9$, non-tradable prices decrease consequently, and given that tradable prices are stable, the inflation decreases with respect to the target level (2\%), which raises monetary authorities' losses under the flexible exchange rate. As a result, the fixed exchange rate regime becomes the optimal choice. The minimal monetary authorities' losses are reached when $a=0.8$ under the flexible exchange rate regime choice (Graphic 11). Consequently, the optimal repartition of compensation fund under the flexible exchange rate regime is $80 \%$ for non-tradable prices and $20 \%$ for tradable prices.

Increasing $b$ (or $c$ ) decreases monetary authorities' losses under both fixed and flexible exchange rate regimes (Tables 8 and 9). However, when $b \geq \frac{4}{3}$ ( or $c>3$ ), monetary authorities' losses under the flexible exchange rate regime become higher then losses under the fixed exchange rate regime. In other words, when nontradable prices (or tradable prices) are reduced by more than $50 \%$ (or by more than $75 \%$ ), the fixed exchange rate regime becomes the optimal choice.

The desegregation of monetary authorities' objective function shows that increasing parameters $b$ ( or $c$ ) reduces monetary authorities' losses relative to real misalignment and to capital account, but raises losses relative to the inflation under the flexible exchange rate regime (Graphics 12 and 13). Accordingly, under the fixed exchange rate regime, increasing parameters $b$ and $c$ raises the compensation funds effect which reduces non-tradable prices and tradable prices, and then reduces the inflation to equalize the target level. However, under the flexible exchange rate regime, increasing $b$ (or $c$ ) raises the exchange rate in nominal 
terms ${ }^{9}$ (nominal depreciation) which raises the inflation. The result indicates that the compensation fund is counter effect under the flexible exchange rate.

\section{Varying elasticities of non-tradable prices}

Varying elasticities of non-tradable prices to the real misalignment $\rho$ and to money supply $v$ doesn't affect largely the results (Tables 10 and 11). The flexible exchange rate regime remains the optimal choice for monetary authorities.

\section{Varying elasticities capital flows}

Increasing the elasticity of capital outflows to real return $\phi$ (Table 12) or the elasticity of capital inflows to real return $\varphi$ (Table 13) reduces monetary authorities' losses under both fixed and flexible exchange rate regimes. However, when $\phi \geq 1.73$, the flexible exchange rate regime becomes the optimal choice, and when $\varphi \geq 1.55$, the fixed exchange rate regime becomes the optimal choice. These results indicate that diminishing returns of capital outflows (more capital outflows with fewer returns) are compatible with the flexible exchange rate regime and that the diminishing returns of capital inflows (more capital inflows with fewer returns) are compatible with the fixed exchange rate regime.

The desegregation of monetary authorities' objective function under the fixed exchange rate regime (Graphic 14) shows that increasing $\phi$ doesn't affect monetary authorities' losses relative to real misalignment and to inflation deviation; but, it reduces losses relative to capital account resulting from the increase of capital outflows. Therefore, the desegregation under the flexible exchange rate regime shows that the increase of capital outflows reduces consequently losses relative to real misalignment (because of real depreciation) and relatively losses relative to inflation deviation, and raises losses relative to capital account.

The desegregation of monetary authorities' objective function under the fixed exchange rate regime (Graphic 15) shows that increasing $\varphi$ reduces consequently losses relative to real misalignment and relatively losses relative to inflation deviation. In contrary, increasing $\varphi$ under the flexible exchange raises losses relatives to real misalignment and inflation deviation, and decreases losses relatives to capital account.

\footnotetext{
$9 \boldsymbol{e}_{n t}=e_{r t}+\pi_{N t}-\pi_{T t}+\boldsymbol{d}_{n t}$
} 


\section{Varying equilibrium real exchange rate growth}

Decreasing the equilibrium real exchange rate $e_{r t}^{\circ}$ (real appreciation) reduces monetary authorities' losses under both fixed and flexible exchange rate regimes (Table 14). The results show that the flexible exchange rate regime is compatible with the real appreciation case, which corresponds to the Moroccan case. When the economy is involved in a real depreciation case, the fixed exchange rate regime becomes the optimal choice.

\section{Varying money supply growth}

Increasing money supply growth $m_{t}$ wraises monetary authorities' losses under both fixed and flexible exchange rate regimes (Table 15). When the money supply is growing by more than $9 \%$, the fixed exchange rate regime becomes the optimal choice (high domestic money supply raises non-tradable prices and then the domestic inflation rate). The results indicate that the fixed exchange rate regime is compatible with an expansionary monetary policy and the flexible exchange rate is compatible with a contractionary monetary policy.

\section{Varying interest rates growth}

The flexible exchange rate is the optimal choice as long as the world interest rate $\mathrm{i}_{\mathrm{t}}^{*}$ is growing within the interval $-7.38 \%<\mathrm{i}_{\mathrm{t}}^{*}<-2.88 \%$ (Table 16) or as the domestic interest rate $i_{t}$ is growing within the interval $-15.37 \%<i_{t}<-4.37 \%$ (Table 17). Accordingly, once the gap between the current domestic interest rate growth and the world interest rate growth (evolution) exceeds the interval ] $-8.49 \% ; 2.51 \%$ [ or once the gap between the domestic interest rate growth (evolution) and the current world interest rate growth exceeds the interval ] $-201 \% ; 349 \%$ [, the fixed exchange rate regime becomes the optimal choice (Graphics 16 and 17). The excess corresponds to capital flight situation when $i_{t} \ll i_{t}^{*}$ and to capital influx when $i_{t} \gg i_{t}^{*}$. This relation between exchange rates and interest rates is of a particular interest for developing countries. Because it has an important role in determining of domestic inflation, real output, exports and imports, etc. (Krušković, 2017).

Finally, increasing the inflation of tradable goods $\pi_{\mathrm{Tt}}$ raises monetary authorities' losses under both fixed and flexible exchange rate regime; however, the flexible exchange rate regime remains the optimal choice (Table 18). As a result, the flexible exchange rate regime allows the economy to adjust to any variation of tradable prices through the nominal exchange rate rather than the real exchange rate. 


\section{Concluding remarks}

In a context of financial liberalization and economic integration, developing countries adopt their specific liberalization policy approaches taking into account their economic circumstances. In this context, Morocco conducts a gradual liberalization of trade flows and capital flows to maximize its advantages from international capital markets. Moroccan monetary authorities initiated a total liberalization of capital inflows and a partial liberalization of capital outflows. This situation contributes to the real exchange rate appreciation and raises the question of risks under the fixed exchange rate regime.

This paper examines the opportunity for the Moroccan monetary authorities to move toward the flexible exchange rate regime under capital account liberalization. Many factors plead for the exchange rate regime flexibilization such as the economic theory predictions (triangle of incompatibilities), recent developing countries experiences and crises (Latin American and East Asia) and institutional recommendations (International Monetary Fund consultations). Moreover, the Moroccan Central Bank has already announced its decision to reform the exchange rate regime.

Based on the findings of Ezzahid and Maouhoub (2014), we developed a new theoretical game model adapted to the Moroccan economic circumstance. The model is represented as a game between four economic agents, namely the monetary authorities, the government, foreign firms, and domestic firms. To determine the optimal exchange rate regime, many economic facts are introduced into the model: the presence of the compensation fund effect, the government strategy to reduce progressively the price subsidies, the foreign firms, the international capital returns, the domestic firms and the presence of restrictions on capital outflows, etc.

Starting with the first simulation based on current economic parameters, the results show that losses of the Moroccan monetary authorities under the flexible exchange rate regime are lower than losses under the fixed exchange rate regime. The desegregation of the objective function's losses shows that the main source of risks is the real exchange rate misalignment and the capital account disequilibrium respectively. Consequently, the choice of the flexible exchange rate regime reduces significantly the monetary authorities' losses. However, losses relative to capital account liberalization under the flexible exchange rate regime remain higher than losses under the fixed exchange rate regime. 
To succeed with their strategy of exchange rate flexibilization, the Moroccan monetary authorities have to liberalize more capital outflows with respect to capital inflows. According to our results, decreasing the parameter $\mathrm{n}$ from 1.10 to 1.04 allows the monetary authorities to reduce more losses under the flexible exchange rate regime. Moreover, it is true that the compensation fund allows price stability under the fixed exchange rate; however, its repartition between nontradable prices and tradable prices and its extent is of the crucial importance.

The optimal repartition according to the results is to allocate $80 \%$ of the compensation fund to non-tradable prices and $20 \%$ to tradable prices; because as BalassaSamuelson effect stipulates for developing countries, non-tradable prices grows more rapidly than tradable prices. As well, increasing $b$ and $c$ reduces the inflation with respect to the target level under the fixed exchange rate regime; but, it produces a counter effect under the flexible exchange rate regime. Consequently, reducing the compensation fund is recommended under the choice of a flexible exchange rate regime. 


\section{References}

1. Agénor, P. (1991). "Credibility and exchange rate management in developing countries”, WP/91/87, IMF working paper. http://papers.ssrn.com/sol3/papers. cfm?abstract id $=885036$

2. Agénor, P. (1994). "Credibility and exchange rate management in developing countries”, Vol. 45, ELSEVIER, Journal of development economics. http://www.sciencedirect.com/science/article/pii/ 0304387894900566

3. Aguir, A. (2018). "Central Bank Credibility, Independence, and Monetary Policy", Journal of Central Banking Theory and Practice, Volume 7: Issue 3, pp. 91-110. https://doi.org/10.2478/jcbtp-2018-0025

4. Aizenman, J. (1994). "Monetary and real shocks, productivity capacity and exchange rate regimes", Economica, $N^{\circ} 61$. http://ideas.repec.org/a/bla/ econom/v61y1994i244p407-34.html

5. Atish, G. Anne-Marie, G. Jonathan, D. and Holger, W. (1996). "Does the Exchange Rate Regime Matter for Inflation and Growth?", Economic issues 2, September 1996, International Monetary Fund. https://www.imf.org/ external/pubs/ft/issues2/

6. Ben Ali, S. M. (2006). "Capital account liberalization and exchange rate regime choice, what a scope for flexibility in Tunisia?", The William Davidson Institute, University of Michigan, Working paper $\mathrm{N}^{\circ}: 815$. http://ideas.repec.org/p/wdi/papers/2006-815.html

7. Chin, D. and Miller, J. (1995). "Fixed vs. Floating rates: a dynamic general equilibrium analysis", Federal Reserve Bank of Minneapolis Research Department Staff Report 194/JV. http://ideas.repec.org/p/fip/fedmsr/194.html

8. Corbo, V. and Hernández, L. (1996). "Macroeconomic Adjustment to Capital Inflows: Lessons from Recent Latin American and East Asian Experience", World Bank Research Observer, 1996, vol. 11, issue 1, 61-85, p.61. https://EconPapers.repec.org/RePEc:oup: wbrobs:v:11:y:1996:i:1: p:61-85

9. Devereux, M. and Engel, C. (2000). "The optimal choice of exchange rate regime: price sitting rules and internationalized production”, University of Washington and NBER.

10. De Vita, G. and Kyaw, G. (2011). "Does the Choice of Exchange Rate Regime Affect the Economic Growth of Developing Countries?" The Journal of Developing Areas, Tennessee State University College of Business, Volume 45, Single Issue, pp. 135-153. https://muse.jhu.edu/article/440739

11. Eduardo, L. and Federico, S. (2003). "To Float or to Fix: Evidence on the Impact of Exchange Rate Regimes on Growth", The American Economic Review, Vol. 93, No. 4 (Sep., 2003), pp. 1173-1193. https://www.aeaweb.org/art icles? $i d=10.1257 / 000282803769206250$ 
12. Ezzahid, E. and Maouhoub, B. (2014). "Capital account liberalization and exchange rate flexibility: scenarios for the Moroccan case”, Economics Discussion Papers, $N^{\circ}$ 2014-18, Kiel Institute for the World Economy. http://www.economics-ejournal.org/economics/discussionpapers /2014-18/file

13. Friedman, M. (1953). "The case of flexible exchange rates", in "Essays in positive economics”, University of Chicago Press, pp. 157-203 (Book).

14. Glauco, D. and Khine, S. K. (2011). "Does the choice of exchange rate regime affect the economic growth of developing countries?", The Journal of Developing Areas, Vol. 45, pp. 135-153. https://www.jstor.org/stable/23215267

15. Hoffmann, M. (2007). "Fixed versus Flexible Exchange Rates: Evidence from Developing Countries” Economica, New Series, Vol. 74, No. 295 (Aug., 2007), pp. 425-449. http://www.jstor.org/stable/4541545

16. Odhiambo, N. M. and Twinoburyo, E. N. (2018). "Monetary Policy and Economic Growth: A Review of International Literature”, Journal of Central Banking Theory and Practice, Volume 7: Issue 2, pp. 123-137.

https://doi.org/10.2478/jcbtp-2018-0015

17. Krušković, D. B. (2017). "Exchange Rate and Interest Rate in the Monetary Policy Reaction Function", Journal of Central Banking Theory and Practice, Volume 6: Issue 1, pp. 55-86. https://doi.org/10.1515/jcbtp-2017-0004

18. Levy-Yeyati, E. and Sturzenegger, F. (2003). "To Float or to Fix: Evidence on the Impact of Exchange Rate Regimes on Growth", American Economic Review vol. 93, No. 4, September, pp. 1173-1193. https://www.aeaweb.org/artic les? $i d=10.1257 / 000282803769206250$

19. Mathias, H. (2007). "Fixed versus Flexible Exchange Rates: Evidence from Developing Countries", Economica, New Series, Vol. 74, No. 295 (Aug., 2007), pp. 425-449. https://www.jstor.org/stable/4541545

20. Mundell, R. (1961). "A Theory of Optimum Currency Areas" The American Economic Review, Vol. 51, No. 4 (Sep., 1961), pp. 657-665. http://www.jstor.org/stable/1812792

21. Mundell, R. (1963). "Capital Mobility and Stabilization Policy under Fixed and Flexible Exchange Rates", The Canadian Journal of Economics and Political Science, Vol. 29, No. 4 (Nov., 1963), pp. 475-485. https://www.jstor.org/stable/139336

22. Vittorio, C. and Leonardo, H. (1996). "Macroeconomic Adjustment to Capital Inflows: Lessons from Recent Latin American and East Asian Experience", the World Bank Research Observer, Vol. 11, No. 1 (Feb.1996), pp. 61-85. https://www.jstor.org/stable/pdf/3986479

23. Zhang, Z. (2001). "Choosing an exchange rate regime during economic transition: the case of China", China Economic Review, $N^{\circ} 12$, pp. 203-226. https://papers.ssrn.com/sol3/papers.cfm?abstract id=941247 


\section{APPENDIX}

\section{Graphics}

Graphic 1: Budget deficit with and without compensation fund

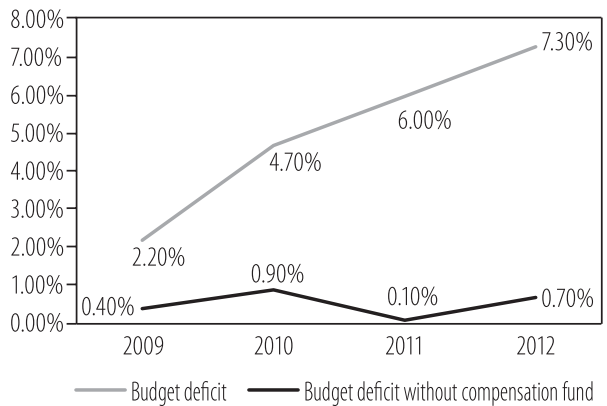

Source: Report on compensation fund, Moroccan 2014 finance bill

\section{Graphic 3: Aggregate M3 in growth rate}

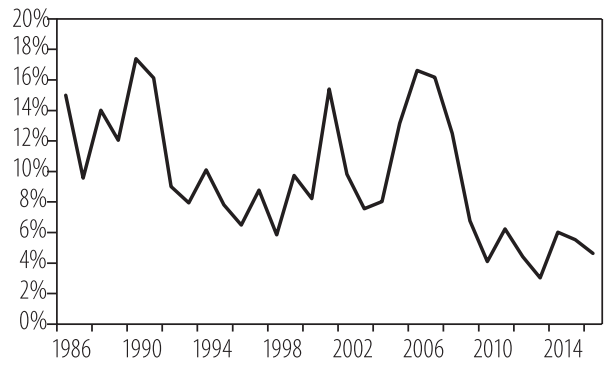

Source: Bank-Al-Maghrib

\section{Graphic 2: Equilibrium real effective} exchange rate

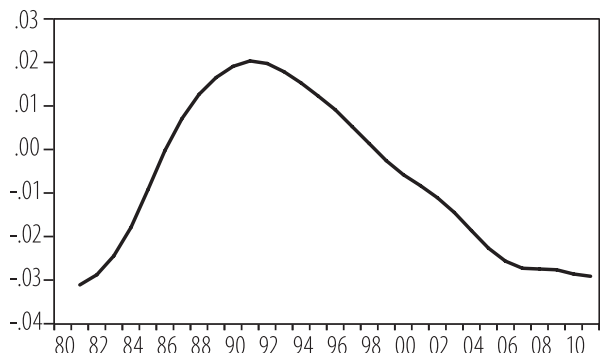



Source: Authors' estimation

Graphic 4: Moroccan interest rate, \%

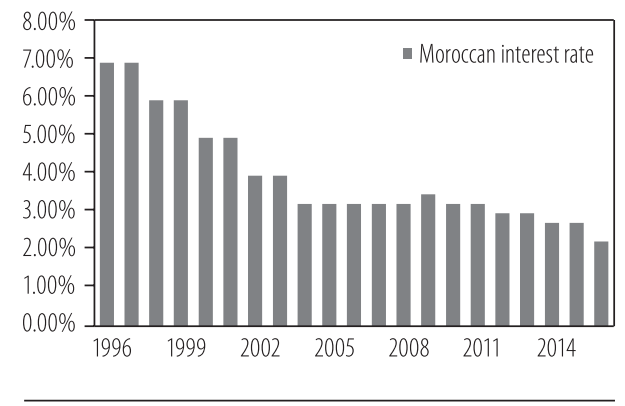

Source: www.tradinfeconomics.com, (Bank Al-Maghrib) 
Graphic 5: US. Interest rate \%, (LR)

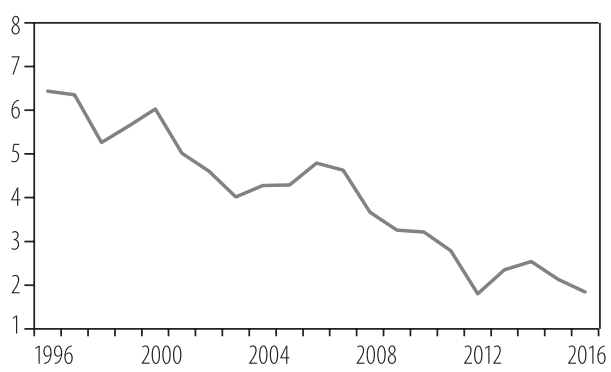

Source: World Bank Data base

Graphic 7: Elasticities of capital outflows $\phi$ and of capital outflows $\varphi$ to real returns

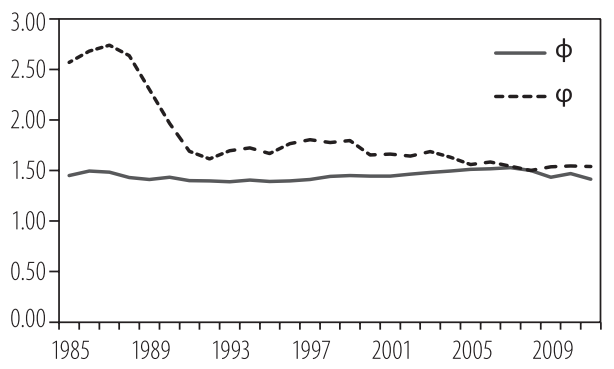

Source: Authors' estimation

Graphic 9: Capital account restrictions and monetary authorities' losses

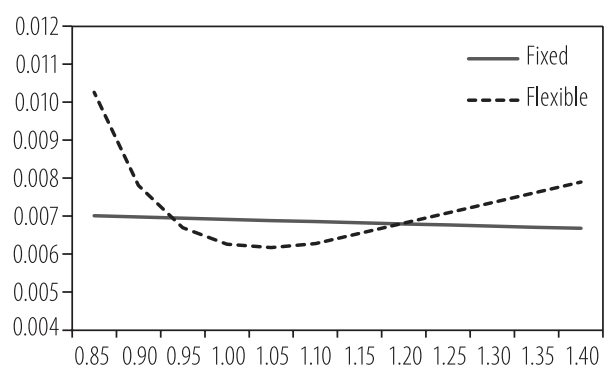

Source: Authors' estimation
Graphic 6: FDI net inflows and net outflows (BoP, current USD)



Source: World Bank Data base

\section{Graphic 8: Inflation, consumer prices} (annual \%)



Source: World Bank Data base

Graphic 10: Capital account restrictions and losses' structure under the flexible exchange rate regime



Source: Authors' estimation 
Graphic 11: Compensation fund repartition and monetary authorities' losses

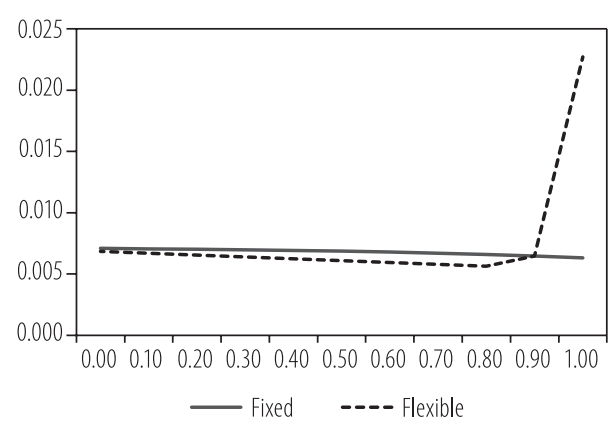

Source: Authors' estimation

Graphic 13: Varying parameter $c$ and desegregation of monetary authorities' losses



Source: Authors' estimation
Graphic 12: Varying parameter $b$ and desegregation of monetary authorities' losses

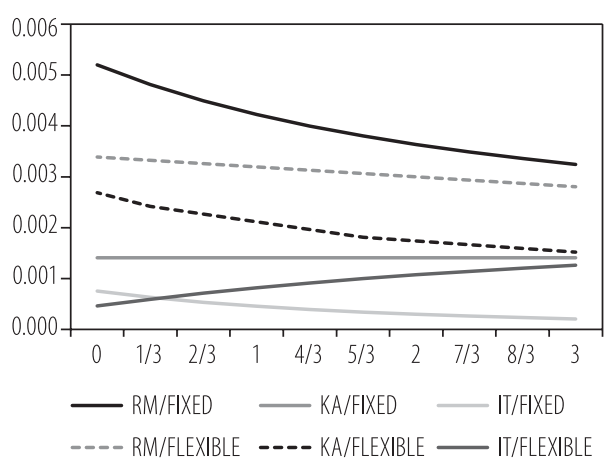

Source: Authors' estimation

Graphic 14: Varying parameter $\phi$ and desegregation of monetary authorities' losses

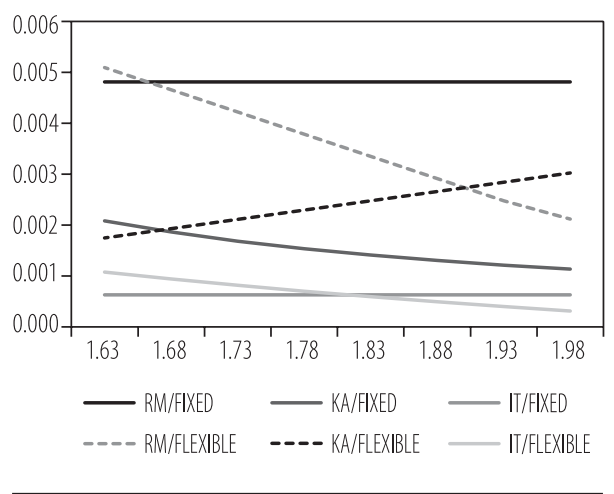

Source: Authors' estimation 
Graphic 15: Varying parameter $\varphi$ and desegregation of monetary authorities' losses

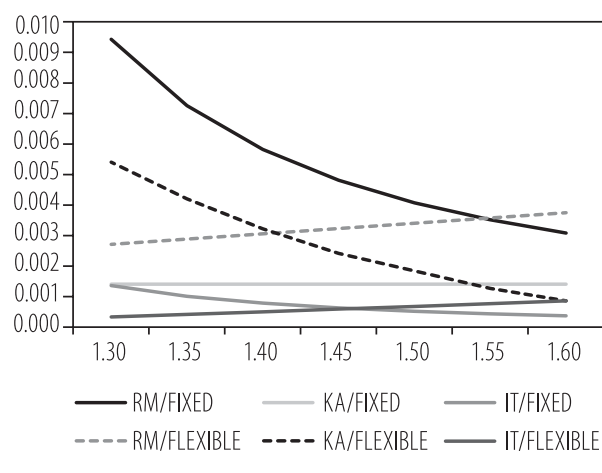

Source: Authors' estimation

Graphic 17: The interest rate gap

$i_{t}-i_{t}^{*}$ and monetary authorities' gap

$W_{t}^{\text {MA/flexible }}-W_{t}^{M A / f i x e x}$ under world

interest rate variation

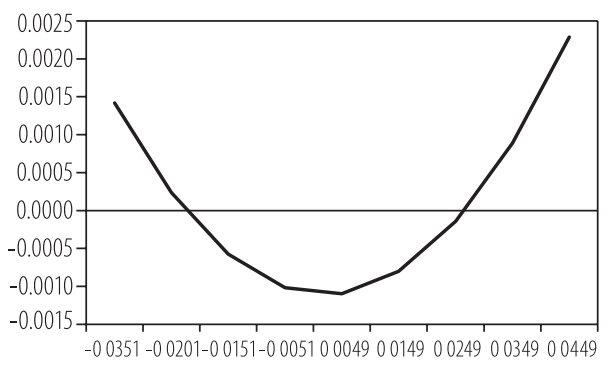

Source: Authors' estimation
Graphic 16: The interest rate gap $i_{t}-i_{t}^{*}$ and monetary authorities' gap $W_{t}^{\text {MA/flexible }}-W_{t}^{\text {MA/fixex }}$ under domestic interest rate variation

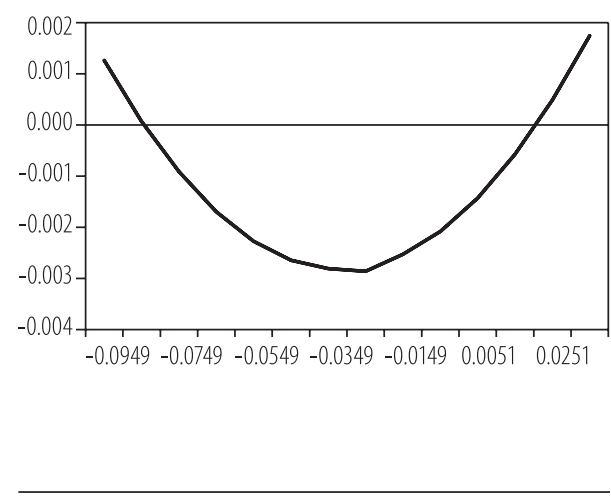

Source: Authors' estimation 


\section{Tables}

Table 1: Estimated parameters and interval of variation

\begin{tabular}{|c|c|c|}
\hline Parameters & Baseline simulation & Interval of variation \\
\hline$\alpha$ & $2 / 7$ & $\{1 / 7,2 / 7,4 / 7\}$ \\
\hline$a$ & $1 / 2$ & $\{1 / 7,2 / 7,4 / 7\}$ \\
\hline$\beta$ & $4 / 7$ & $\{1 / 7,2 / 7,4 / 7\}$ \\
\hline$\delta$ & 0.3 & $0.5<1-\delta<0.8$ \\
\hline$\vartheta$ & $1 / 7$ & $0<\vartheta<1$ \\
\hline$n$ & 1.1 & $0.75<n<1.50$ \\
\hline$b$ & $1 / 3$ & $0<b<3$ \\
\hline$c$ & $1 / 4$ & $0<c<3$ \\
\hline$\tau$ & $1 / 3$ & $\{1 / 3,2 / 3\}$ \\
\hline$\mu$ & $2 / 3$ & $\{1 / 3,2 / 3\}$ \\
\hline$\rho$ & 0.4 & $0.25<\rho<0.55$ \\
\hline$v$ & 0.6 & $0.45<v<0.75$ \\
\hline$\phi$ & 1.83 & $1.68<\phi<1.98$ \\
\hline$\varphi$ & 1.45 & $1.30<\varphi<1.60$ \\
\hline$e_{r t}^{\circ}$ & -0.01917 & $-0.03917<e_{r t}^{\circ}<+0.02417$ \\
\hline$p_{t}^{\circ}$ & 0.02 & none \\
\hline$m_{t}$ & 0.0509 & $0.0109<m_{t}<0.1009$ \\
\hline$\gamma_{t}^{*}$ & 0 & none \\
\hline$i_{t}^{*}$ & -0.0688 & $-0.1088<i_{t}^{*}<0.0688$ \\
\hline$\gamma_{t}$ & 0 & none \\
\hline$i_{t}$ & -0.0537 & $-0.0937<i_{t}<0.0437$ \\
\hline$\pi_{T t}$ & 0.01 & $0.005<\pi_{T t}<0.03$ \\
\hline
\end{tabular}

Table 2: Monetary authorities' losses under fixed and flexible regimes

\begin{tabular}{lc}
\hline Choices & Monetary authorities' losses \\
\hline Fixed Exchange rate regime & 0.006855 \\
\hline Flexible Exchange rate regime & 0.006280 \\
\hline
\end{tabular}


Table 3: Desegregation of monetary authorities' losses under fixed and flexible regimes

\begin{tabular}{|c|c|c|c|c|}
\hline Choices & $\begin{array}{l}\text { objective function's } \\
\text { components }\end{array}$ & Losses & Percentage & Total \\
\hline \multirow{3}{*}{$\begin{array}{l}\text { Fixed Exchange } \\
\text { rate regime }\end{array}$} & Real misalignment RM & 0.004812 & $70.20 \%$ & \multirow{3}{*}{0.006855} \\
\hline & Inflation targeting IT & 0.000631 & $9.20 \%$ & \\
\hline & Capital account KA & 0.001412 & $20.60 \%$ & \\
\hline \multirow{3}{*}{$\begin{array}{l}\text { Flexible Exchange } \\
\text { rate regime }\end{array}$} & Real misalignment RM & 0.003265 & $51.99 \%$ & \multirow{3}{*}{0.006280} \\
\hline & Inflation targeting IT & 0.000594 & $9.46 \%$ & \\
\hline & Capital account KA & 0.002421 & $38.55 \%$ & \\
\hline
\end{tabular}

Table 4: Monetary authorities' losses and capital account restrictions

\begin{tabular}{|c|c|c|c|c|c|c|c|c|c|}
\hline$n$ & \multicolumn{2}{|r|}{0.80} & \multicolumn{2}{|c|}{0.85} & \multicolumn{2}{|l|}{0.90} & 0.95 & \multicolumn{2}{|r|}{1} \\
\hline Capital flows & \multicolumn{7}{|c|}{$k_{o t}>k_{i t}$ capital flight } & \multicolumn{2}{|c|}{$k_{i t}=k_{o t}$} \\
\hline Fixed & \multicolumn{2}{|c|}{0.007043} & \multicolumn{2}{|c|}{0.007011} & \multicolumn{2}{|l|}{0.006979} & 0.006948 & \multicolumn{2}{|c|}{0.006917} \\
\hline Flexible & \multicolumn{2}{|c|}{0.015576} & \multicolumn{2}{|c|}{0.010262} & \multicolumn{2}{|l|}{0.007811} & 0.006700 & \multicolumn{2}{|c|}{0.006261} \\
\hline$n$ & 1.05 & 1.10 & 1.15 & 1.20 & 1.25 & 1.30 & 1.35 & 1.40 & 1.45 \\
\hline Capital flows & \multicolumn{9}{|c|}{$k_{i t}>k_{o t}$ capital influx } \\
\hline Fixed & 0.006886 & 0.006855 & 0.006825 & 0.006796 & 0.006766 & 0.006737 & 0.006708 & 0.006680 & 0.006652 \\
\hline Flexible & 0.006175 & 0.006280 & 0.006487 & 0.006747 & 0.007031 & 0.007323 & 0.007614 & 0.007897 & 0.008170 \\
\hline
\end{tabular}

Table 5: Monetary authorities' losses and preferences

\begin{tabular}{|c|c|c|c|c|c|c|}
\hline $\begin{array}{l}\text { Order of } \\
\text { importance }\end{array}$ & $\begin{array}{l}\alpha=1 / 7 \\
\beta=2 / 7 \\
\vartheta=4 / 7\end{array}$ & $\begin{array}{l}\alpha=1 / 7 \\
\vartheta=2 / 7 \\
\beta=4 / 7\end{array}$ & $\begin{array}{l}\beta=1 / 7 \\
\alpha=2 / 7 \\
\vartheta=4 / 7\end{array}$ & $\begin{array}{l}\vartheta=1 / 7 \\
\alpha=2 / 7 \\
\beta=4 / 7\end{array}$ & $\begin{array}{l}\vartheta=1 / 7 \\
\beta=2 / 7 \\
\alpha=4 / 7\end{array}$ & $\begin{array}{l}\beta=1 / 7 \\
\vartheta=2 / 7 \\
\alpha=4 / 7\end{array}$ \\
\hline Fixed & 0.008368 & 0.005861 & 0.010615 & 0.006855 & 0.011350 & 0.012604 \\
\hline Flexible & 0.010251 & 0.006648 & 0.012041 & 0.006280 & 0.009737 & 0.011520 \\
\hline
\end{tabular}

Table 6: Monetary authorities' losses and economic openness rate

\begin{tabular}{cccccccc}
\hline $1-s$ & 0.50 & 0.55 & 0.60 & 0.65 & 0.70 & 0.75 & 0.80 \\
\hline Fixed & 0.009102 & 0.008417 & 0.007817 & 0.007298 & 0.006855 & 0.006485 & 0.006181 \\
\hline Flexible & 0.007569 & 0.007190 & 0.006849 & 0.006546 & 0.006280 & 0.006052 & 0.005860 \\
\hline
\end{tabular}




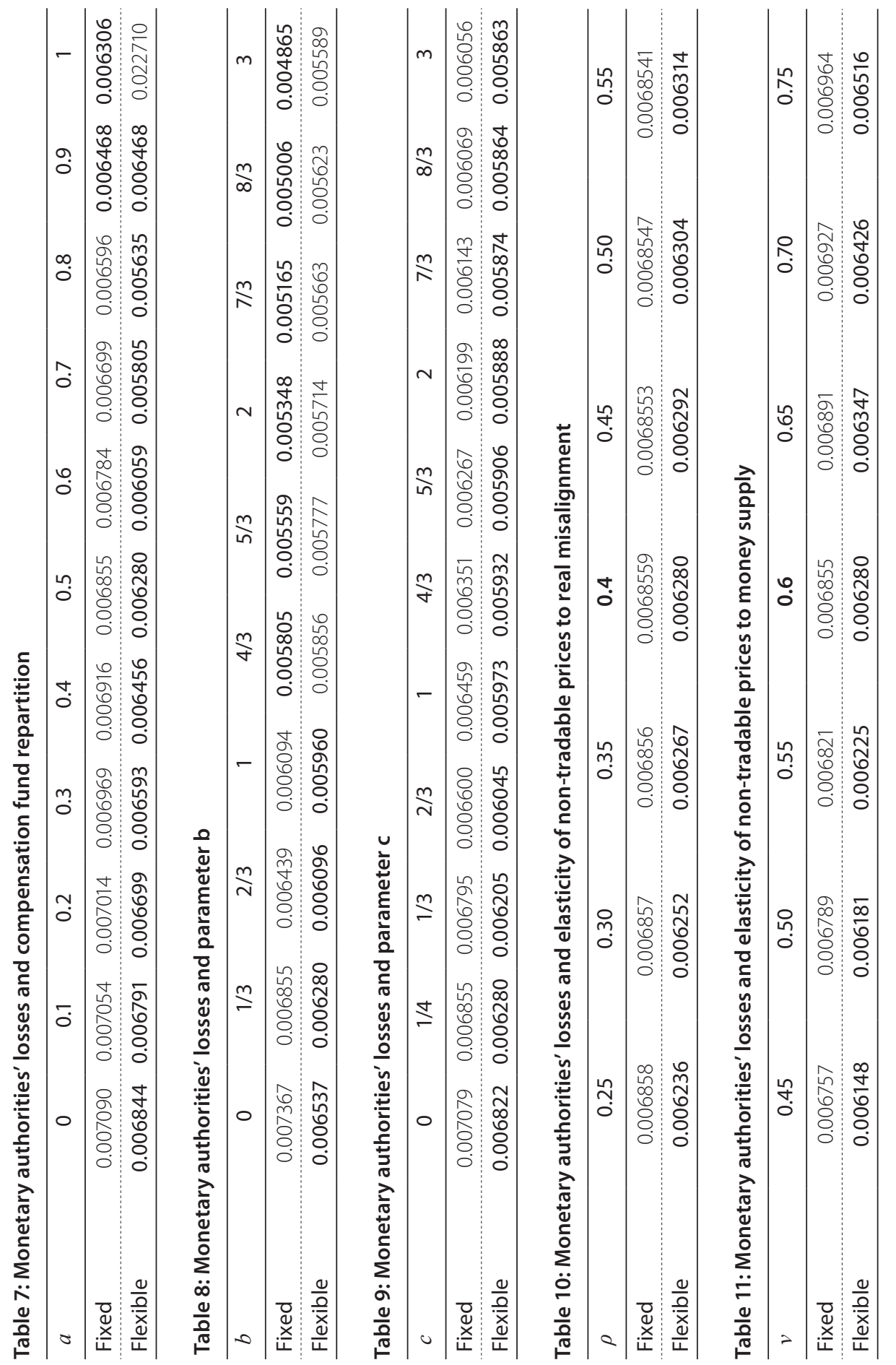




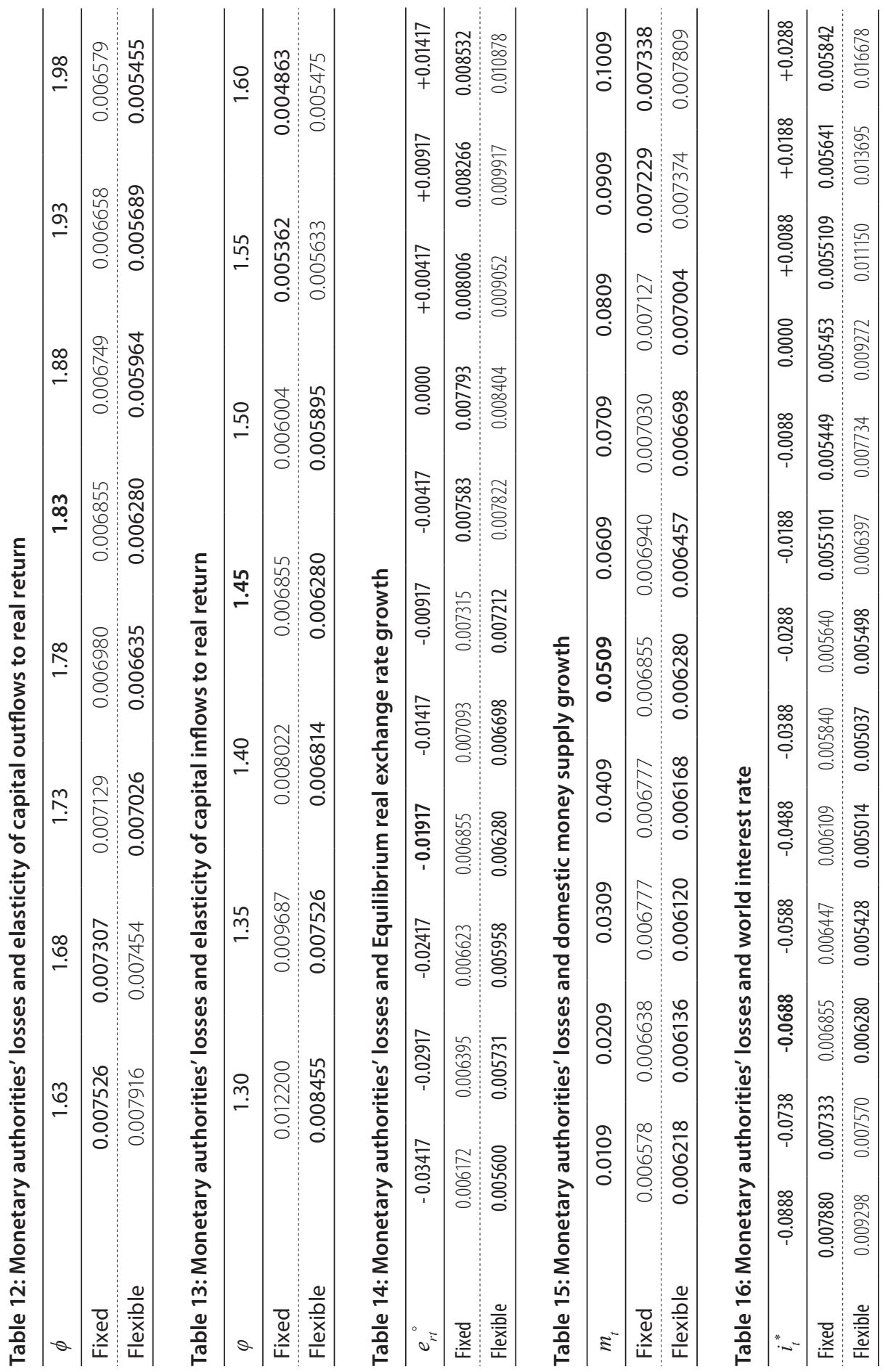


Table 17: Monetary authorities' losses and domestic interest rate

\begin{tabular}{lrrrrrrr}
\hline$i_{t}$ & -0.1637 & -0.1537 & -0.1437 & -0.1337 & -0.1237 & -0.1137 & -0.1037 \\
\hline Fixed & 0.049478 & 0.043853 & 0.038578 & 0.033653 & 0.029079 & 0.024854 & 0.020979 \\
\hdashline Flexible & 0.050737 & 0.043922 & 0.037662 & 0.031957 & 0.026806 & 0.02221 & 0.018169 \\
\hline \hline$i_{t}$ & -0.0937 & -0.0837 & -0.0737 & -0.0637 & -0.0537 & -0.0437 & -0.0337 \\
\hline Fixed & 0.017545 & 0.014279 & 0.011455 & 0.00898 & 0.006855 & 0.005081 & 0.003656 \\
\hline Flexible & 0.014682 & 0.011749 & 0.009372 & 0.007549 & 0.006280 & 0.005566 & 0.0054 \\
\hline \hline$i_{t}$ & -0.0237 & -0.0137 & -0.0037 & 0 & 0.0037 & 0.0137 \\
\hline Fixed & 0.002582 & 0.001858 & 0.001483 & 0.001433 & 0.001432 & 0.001666 \\
\hline Flexible & 0.005407 & 0.005802 & 0.006752 & 0.008257 & 0.008954 & 0.009728 \\
\hline
\end{tabular}

Table 18: Monetary authorities' losses and the inflation of tradable prices

\begin{tabular}{lcccccc}
\hline$\pi_{T t}$ & 0.005 & 0.010 & 0.015 & 0.020 & 0.025 & 0.030 \\
\hline Fixed & 0.006264 & 0.006855 & 0.007486 & 0.008154 & 0.008862 & 0.009609 \\
\hline Flexible & 0.005781 & 0.006280 & 0.006855 & 0.007507 & 0.008234 & 0.009038 \\
\hline
\end{tabular}

